\title{
Critical geography in Germany: from exclusion to inclusion via internationalisation
}

\author{
B. Belina ${ }^{1}$, U. Best ${ }^{2}$, and M. Naumann ${ }^{3}$ \\ ${ }^{1}$ Goethe Univ. Frankfurt, Department of Human Geography, Robert-Mayer-Straße 6-8, 60325 Frankfurt am Main, Germany \\ ${ }^{2}$ Univ. of British Columbia, Centre for Social, Spatial \& Economic Justice, 3333 University Way, Kelowna, BC, V1V 1V7, \\ Canada \\ ${ }^{3}$ Univ. of Hamburg, Department of Geography, Bundesstraße 55, 20146 Hamburg, Germany
}

Received: 28 November 2008 - Published in Soc. Geogr. Discuss.: 18 March 2009

Revised: 21 August 2009 - Accepted: 29 August 2009 - Published: 13 October 2009

\begin{abstract}
Critical perspectives have become more visible in German human geography. Drawing on an analysis of the debate around the German reader "Kulturgeographie" published in 2003, we suggest that this case provides new insights into the "geography of critical geography". We briefly discuss the history of critical geography in Germany, leading to a comparison of the conditions of critical geography around 1980 and in recent years. The focus is on two factors in the changed role of critical perspectives in German geography: (1) the growing internationalisation of German geography, which opened new avenues and allowed new approaches to enter the discipline; and (2) the high citation indices of "critical" journals, which leads to an enhanced reputation and a high significance of international critical geography in the German discipline. However, we draw an ambiguous conclusion: the increased role of critical approaches in German geography is linked to a growing neoliberalisation of academia and a decline of critical approaches in other disciplines.
\end{abstract}

\section{Introduction: a critical turn in German geography?}

Recent debates in critical geography have stressed the need for a "critical geography of critical geography" (Berg, 2004). While the majority of contributions have criticized the "Anglo hegemony" of British and North American critical geography over "other" critical geographies, few contributions have analysed the impact of growing internationalisation on the status of critical geography within the wider discipline of geography. In this paper, we attempt such an analysis, using the case of Germany. We do so, first, because we think

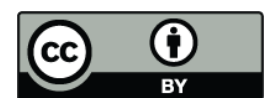

Correspondence to: B. Belina (belina@em.uni-frankfurt.de) that power structures within the (nationally organized) discipline are far more significant for the concrete situation of critical geography in any particular country than the international relations within critical geography. Second, and this is the good news, something seems to be happening in German human geography: explicitly left-wing perspectives are gaining in importance. ${ }^{1}$

While in general the left in German universities is facing declining resources and impact on debates inside and outside academia, while German geographers are faced with the same neoliberalising developments as colleagues in other disciplines and live in the same precarious situation (cf. for the situation of radical academia in Germany: Bultmann, 2008; Bultmann and Schöller, 2003; Brüchert and Wagner, 2007; Sambale et al., 2008; for its gender dimension cf. Notz, 2008), and while many radicals conclude that the left has to create new sites of discourse outside academia (Demirovic, 2006; Bretthauer and Fromberg, 2008), our impression is that geographers with a left wing theoretical and/or political background are relatively better off in that respect - at least better than they used to be. There actually is something of a "critical turn" in German geography.

Having said that, we have to emphasize that this turn departs from a position that would have to be characterized as remarkably un-radical. Geography and geographical discourse in Germany are nowhere near the centre of critical academic discourse, as Mitchell (2004) argues is the case in the US, and there are no critical geographers (or any geographers for that matter) who have, or attempt to have, an impact on public debates (contrary to elsewhere, cf. Ward, 2007; Castree, 2006). German geography is dominated by varying strands of decidedly applied research imbued with a fair amount of political and academic conservatism. It is

\footnotetext{
${ }^{1}$ It should be noted, however, that due to the financial crisis, some things might be shifting in wider academia.
} 
a discipline without a radical tradition, as opposed to many humanities and social sciences in Germany. ${ }^{2}$

There is certainly a great deal of heterogeneity between the developments in this critical turn. Let us point out just a few of the more bottom-up initiatives within recent years: from 1999 to 2004 a group of German speaking feminist geographers organised "reading weekends" with the British Geographer Doreen Massey (BASSDA, 2006); a Germany-wide network of critical geography students was established in 2005 and is still running; two textbooks on feminist geography were published recently (Fleischmann and Meyer-Hanschen, 2005; Strüver, 2005); a theme issue on Marxism was published in Geographische Revue in 2001 and one on critical geography in 2008; Antipode lectures (since this year ACME lecture) have been organised at the biannual German geographers' conference, the Geographentag, since 1999; a new book series for radical geography was established with a left wing publisher; a German issue of the online journal ACME was published in 2008, lecture series on critical geography were organized in Potsdam, Münster, Berlin, Göttingen and other places; two conferences on critical geography took place in Frankfurt in 2008 and 2009; and the recent conferences of the International Critical Geography Group (ICGG) were attended by a considerable number of German geographers. Also, within established German geography, not explicitly leftist, but relatively open-minded annual conferences on Neue Kulturgeographie (new cultural geography) have been attended by dozens of younger geographers since 2004 and offered a space for critical approaches; and numerous Anglo-American radical geographers were invited to the Hettner Lecture series in Heidelberg (1997-2006).

In this paper we want to stress the importance of the internationalization of critical geography in these developments and the positive impact it has had on what we refer to as the critical turn in German geography. We will proceed as follows: In part 2 we sketch out what we mean by "critical". In parts 3 and 4, we discuss how the struggle over hegemony within German geography produces the line between critical and un-critical geography, using controversies from, first, around 1980 and, second, recent years. We conclude in part 5 by discussing the changing role of international debates for German geography, and its relation to the status of "critical" approaches.

\footnotetext{
${ }^{2}$ Nowhere is this more evident than in textbooks and introductory literature for geography students (cf. Schenk and Schliephake, 2005a). In such books, critical schools of thought (like feminism, political ecology, Marxian political economy, postcolonial studies, whiteness studies) and typical topics of interest to critical geographers (such as urban struggles, race and gender inequality or environmental justice) are barely mentioned (for a contrasting example cf. Gebhardt et al., 2007).
}

\section{What is "critical" in German geography?}

When it comes to definitions of "critical geography", we think Blomley is quite right to point to the simple fact that "all scholarship entail[s] critical thinking" (2006:87). "Uncritical geography" is as much an oxymoron as "uncritical science" in general (Markard, 2005:25), as each and every geographer will claim to be critical (of whatever; cf. Belina, 2008a). Thus, there is a problem in identifying the "critical" in geography; and this is why we do not intend to define "what's critical".

Furthermore, and unlike in the English language, a distinction between radical and critical geography does not make much sense in a German context. Especially "radical geography" cannot be and is almost never translated into German - if it is used, it remains in English, as "radical", not "radikal". Thus, there is no debate about the difference between "radical" and "critical" geography, as there is in the Anglophone context (cf. Castree, 2000; Peet, 2000). There is also something more specific to the German debate: the idea of something (or someone) being "radikal" is often used from a centrist-vs-bipolarist perspective in order to point out that there are two extremes - left and right - and the "centre" is the location of reason. Left equals right in this perspective. In the 1970s, however, especially in the "Radikalenerlass" (the decision of the German ministers of the Interior in 1972 to get rid of "radicals", defined as people whose support for "free democratic basic order" is doubtable, from public services, incl. schools, universities), the term specifically targeted left-wing "radicals".

In this article, we use the term "Marxist geography" when talking about developments up until the 1980s, as this was the dominant left/critical perspective within the discipline. As we enter contemporary debates, we use the term "critical geography", because to a certain degree the development of the debates parallels those in Anglophone geography. When we use the term "left", we refer to debates and practices that take place beyond academia and comprise more explicit political positions.

As a further means to avoid a classificatory system, instead of constructing any form of abstract standard for "critical geography", we pursue a different path, focusing on concrete debates. From these, we extract the relational definition of what is being perceived as a leftist/radical/critical deviation from mainstream geography. It is only in the concrete "struggle over objectivity" (Gramsci, 1995:1412ff; cf. Haug, 2001) that the distinction between "critical" and "un-critical" geography is produced within institutional geography - that tiny little state apparatus (cf. Althusser, 1977). And it is this power laden distinction that we want to reconstruct from controversies within German geography that involved an intervention or reaction from what was seen and defined as the left, and that were fought over in public (i.e. the discipline's equivalent: publications), as it is here that struggles over hegemony become visible and are documented. 
There have not been many such controversies in the past few decades, and of these, many did not find their way into journals or discussion papers. Feminist geography, for example, was definitely not welcomed by male-dominated mainstream German geography in the 1980s and 1990s (cf. Fleischmann and Meyer-Hanschen, 2005:43-51). The same seems to be true for the works of Mechthild Rössler (1990), Horst-Alfred Heinrich (1991), Gerhard Sandner (1995; Sandner and Rössler, 1994) and others on the role of German geography and geographers in Nazi Germany. But these controversies over the history of German geography and feminism were not fought out in public (for the history of geography, Fahlbusch (1999) and Wardenga and Böhm (1999) are rare exceptions).

We focus on two controversies that allow us to compare and contrast the state of affairs around 1980 with the situation more than a quarter century later: first, the controversy following the publication of Eugen Wirth's book Theoretische Geographie ["Theoretical Geography"] (1979) and second, the one that followed the publication of the textbook Kulturgeographie ["Cultural Geography"], edited by Hans Gebhardt, Paul Reuber and Günther Wolkersdorfer (2003a). In each case, we start with more general reflections on the state of radicalism and Marxist/critical geographers in the wider societal context.

One last remark before getting started: As we are interested in understanding today's situation, we limit our analysis to West German human geography, as theoretical approaches of human geography from the German Democratic Republic (e.g. Schmidt-Renner, 1966) had no impact on post-1989 German geography.

\section{The situation around 1980}

\subsection{The left in German geography until 1980}

To understand the extent to which today's geography is moving towards the left, it is necessary to recall the characteristics of the discipline in the period from post war West Germany up until the 1980s. No such thing as a sustainable Marxian or otherwise leftist influence made it into geography's mainstream discourse. Any tradition following Wittfogel's (1929) seminal three-piece paper on Geopolitics, Geographical Materialism and Marxism was destroyed in Nazi Germany.

In the founding years of the Federal Republic of Germany after WWII, marked by anti-communist propaganda and repression (Brünneck, 1978; Gössner, 1998) and with continuities from the Nazi regime in many parts of public life, left wing academics were very much on the margin. It was not until the 1960s that voices from the left were able to gain influence in many social sciences - with the exception of geography. The main reason for this, apart from the continuity in personnel within the geographic community after 1945 (Sandner, 1995), seems to be its selfdefinition as being between and/or beyond the natural/social science divide (cf. Schmithüsen, 1970:434, but also Schenk and Schliephake, 2005b or Ehlers, 2005b for recent examples of a similar position). This placed the discipline outside of any relevant social theory discourse (be it Marxist, bourgeois or otherwise). While pre-1960s Anglophone geography was described in similar ways (cf. Smith, 2001:9), we think that post-war mainstream German geography was even more extreme in its wilful, self-imposed isolation from social theory (individual attempts such as Wolfgang Hartke's notwithstanding, cf. Hartke, 1956). This ended with the 1969 Geographentag (the biannual central conference of German language geography) in Kiel that marked the end of the dominance of traditional geography and opened the discipline to new influences, especially the quantitative revolution. While this parallels to some extent the development that enabled Marxism to enter the picture in the US, no Marxian or other radical input made its way into German geography after 1969. We think that this was largely due to three factors:

- The objectives of those who introduced social theory: When students and young faculty members, backed by some professors, heavily criticised German geography for being "un-scientific" and "irrelevant" in Kiel in 1969 (Berliner Geographenkreis, 1969), radicalism only played a minor role (cf. Bahrenberg, 1996:41-43). Although some of the students' critique was influenced by the radical political discourse of the time, the critique drew primarily on positivist spatial science (Bartels, 1968) and aimed at "relevance", i.e. participation in state planning (cf. Ganser, 1970).

- Gate-keeping: Students and young faculty members in geography leaning towards the left after 1969 were faced with a conservative academic community that was able to "keep them out" successfully. This was facilitated by the German academic system of the time (which has changed only slightly since then): All power was concentrated in the hands of the Ordinarien, i.e. the highest ranking professors, some of whom were able to make and break careers also beyond their "own" department. It was up to them to decide whom to graduate, whom to allow for a $\mathrm{PhD}$ and a Habilitation ("second book" professorial qualification, necessary to become university professor), and whom to give a position. And they remained the direct superior to everyone they hired, only Ordinarien themselves were not personally dependent on other individual academics. ${ }^{3}$ In the relatively small discipline of German human geography, individual chairs could control the appointments at several universities through the allegiance their former protégés paid them.

\footnotetext{
3 This is why the first question a German professor will ask a junior colleague will usually not be "What is your work about?", but: "Who do you work for?"
} 
- Radicals in the German educational system: The "German autumn" of 1977 - when "terrorist hunts" and a "red scare" swept through West Germany - put an end to the "invasion" of the German educational system by left-wing radicals. In many other disciplines, radicals had been able to obtain professorships before that date, especially at newly founded "reform universities" (Bremen, Bielefeld, Bochum) and at universities with at least some radical tradition (Frankfurt, Marburg, Berlin). Being a step or two behind other disciplines, this was not the case in geography.

Within this institutional and political situation, it is not surprising that the rare attempts at Marx-inspired or Marxian research published by singular academic geographers or groups of students did not have much of an impact. The student journals of the 1970s (Geografiker, Roter Globus and Geographie in Ausbildung und Planung), Beck's (1973) Marxian critique of bourgeois economic geography, his or Eisel's (1982) sketches of a geography based on Marxian social theory, Eisel's fundamental critique of the geographical paradigm (1980), Leng's (1973) Marxian critique of the "Munich school", Frieling's (1980) critique of social ecology and sketch of a Marxian urban geography or Beck's (1985) Marxian critique of Christaller's central place theory did not have much influence on geographical mainstream discourse (Best, 2009). The response of the discipline was essentially one of silence. However, there was one debate in German geography that involved a minor Marxian position: Kneisle's (1980, 1983) critique of Eugen Wirth's (1979) Theoretische Geographie. It is to this debate that we now turn in order to analyse how and in what respect "left voices" were acceptable or capable of inclusion.

\subsection{Marxism in the controversy following Eugen Wirth's Theoretische Geographie (1979)}

Theoretische Geographie (TG) by Eugen Wirth was (and still is) one of the few attempts at a theoretical foundation of the discipline in Germany, in fact a conservative attempt to secure the position of traditional regional geography ["Länderkunde"]. Following its turn to positivism and statistics after Kiel and the "theoretical turn" of international geography, devastating critiques of Länderkunde had been voiced by positivists such as Bartels (1968), Bahrenberg (1972) and Hard (1973) - and, in fact, had already won the battle. In 1979 however, the still powerful Ordinarius Eugen Wirth published $T G$ trying to combine "scientific" geography and Länderkunde. In $T G$, Wirth attempted much more than an overview of theoretical approaches in geography (at that time mainly quantitative). He proposed a theory of geography which combined a theory of science, positivist approaches, recent methodological advances, but also reserved a space for traditional geography. Länderkunde was supposed to be the highest stage of geography, combining the different subfields and guaranteeing the unique position of geography vis à vis other disciplines.

The book sparked a lively debate within German geography, consisting primarily of devastating critiques mainly by proponents of the quantitative turn (Bahrenberg, 1979; Bartels, 1980; Dürr, 1979; Kneisle, 1980; Petersen, 1980; Sedlacek, 1980). As the public nature of the controversy shows, this was a struggle for hegemony in German geography, one about the definition of what German geographers should and were allowed to do and think. Wirth explicitly addresses students (1979:9) and, as one critic observes, "younger (or more naïve?) colleagues" (Bartels, 1980:126). TG is full of judgement about geographical approaches and geographers and is driven by a "massive desire to convince" (ibid.:124). Our aim in analysing this struggle is to shed some light on "what was left" in German geography around 1980 by focussing on the role political arguments and Marxism played in it.

As mentioned already, the criticism of $T G$ was damning. Bahrenberg (1979), building his argument on Popper (1962), characterizes Wirth's (1978) attempt to ground Länderkunde in positivist theory of science as being "in vain" (Bahrenberg, 1979:147). Bartels criticises the "conservative embrace of the [positivist] revolution" (1980:121). In both critiques, published in German geography's most important journal, political aspects are absent. Both focus on the "progress" of the discipline.

The more interesting contributions for our question can be found in a discussion paper series initiated by the quantitative geographer André Kilchenmann (Dürr, 1979; Kneisle, 1980; Sedlacek, 1980; Petersen, 1980). As Kilchenmann explains in a foreword to the first discussion paper, his original idea was to have various geographers comment briefly on $T G$ in one discussion paper. However, this could not be realised as the vast majority of possible contributors refrained from joining the project. Various reasons were given, among them "fear of personal consequences resulting from a too critical statement" (Kilchenmann, 1979:2). Of the contributions that were published, only two came from German pre-tenure staff. While Dürr (1979) tried to be as polite as possible, Alois Kneisle (1980) was very harsh. These two contributions and Wirth's reaction are especially interesting for us. Where was the frontline in the "war of positions" over hegemony (Gramsci, 1992:868) between mainstream and left geography as defined by mainstream geography? What role did Marxism and Marxism-inspired geography, already quasi hegemonic in Anglo-American geography at the time (Smith, 2001), play in this controversy?

The debate initially revolved around the issue of "openness". In the first paper in the series, Heiner Dürr (1979) criticises Wirth for, among many other things, missing out whole strands of literature without giving reasons for this omission (Dürr, 1979:49-53). Unlike Bartels (1980:121), he not only misses the work of Hard (1973) and the "Munich school of social geography" (Ruppert and Schaffer, 1969; cf. Leng, 1973), but also Marxism and Marxian authors. Positioning 
himself as a liberal wishing to develop an "open geography" from a critical-rationalist standpoint (i.e. not being a Marxist himself), Dürr criticises Wirth for his "crass, yet not explicit anti-Marxism" (Dürr, 1979:49).

In reply, Wirth claims to be more rather than less open than Dürr (Wirth, 1980:5-15), while also emphasizing his liberalism (ibid.:20) and giving three reasons for his silence concerning Marxism. First, his biography: he saw everything he needed to know about Marxism as a prisoner of war in the Soviet Union and during "travels and research in Marxismoriented countries" (ibid.). Second, being a "pluralist" he cannot accept the "dogmatically hardened basic structure of the Marxian doctrine" (ibid.). Third, with reference to Marxinspired work by German geographers, he considers Marxian analysis to be of low quality and "weak" (ibid.:22).

Here is a fundamental difference between the German and the Anglo-American or French situation in the 1970s and 80s that is worth emphasising. Commenting on Dürr's reference to Marx, Engels and Lenin, Wirth asks: "Does he really expect me to read [...] Marxist classics [...]?" (1980:22) Unsurprisingly, he was not planning to do so - because, we argue, he did not have to. Contrary to anti-Marxist colleagues such as Peter Gould (1988) in the US or Paul Claval (1977) in France, Wirth does not see any need to "prove" that Marx is no good for geographers, for example by claiming that Marx was not interested in "space". The reason for Wirth's position is simply that he sees no worthy opponent in German geography - and German geography is all he is interested in. His enemies are positivists who ruin unified geography and $L a ̈ n d e r k u n d e$. They are the reason for $T G$, not some lonely Marxists who criticise both traditional and positivist geography.

What is at stake in this debate? Marxism is referred to by Dürr as an example of what is missing in $T G$ and as proof for the lack of "openness" on Wirth's part. Although Dürr mentions the importance of "geographical" topics, such as concentration in Lenin (1965 [1917]) or segregation in Engels (1976 [1845]), the structure of his argument abstracts from the content and insights provided by Marxian reasoning. What Dürr bemoans is that something is missing, something that is being discussed in Anglo-American and French geography (Dürr, 1979:52f). As opposed to Wirth, whose sole public is German geography, Dürr is interested in international debates. As the first principle of his "open geography" is inclusion of "all possible methodological positions" (ibid.:61) - a claim that Wirth (1980:17-18) can easily and rightly dismiss as impossible - for Dür the exclusion of Marxism in $T G$ is to be criticised no matter what Marxist geographers actually do or write, because it is a relevant approach in international debates. Marxism, in this respect, is just an example of Wirth's lack of openness and Dürr invokes it instrumentally.

As Kneisle (1983:91) points out, "pluralism" for Wirth is a strategy to exclude any approach he does not like, including all leftist approaches. By calling himself a pluralist, Wirth claims to be open though in reality this means that just one position - his own - is truly pluralist and therefore privileged. Implicitly, then, Wirth's dismissal of Marxism is a political judgement that is based on the power of his position and not on a discussion of arguments. At this time, Wirth was not the towering figure in German geography anymore that he used to be. His position had been undermined by the quantitative revolution and his book had been almost consensually dismissed by the new key figures of geography. Still, this discussion can first of all shed some light on the time when traditional geography was still strong in Germany. Second, it demonstrates that although traditional geography had by now lost the struggle, it was not critical or Marxist geography that had won - it was hardly mentioned in the mainstream debate. The quantifiers - just like Wirth - did not consider Marxism to be a perspective that deserved any greater consideration.

The two contributions to the controversy following $T G$ written from a Marxist standpoint were therefore more or less ignored within the debate. Petersen (1980), a Danish geographer, states that Wirth's geography is a "national geography" (ibid.:3), one that "puts German geography even further offside" (ibid.:4). Kneisle (1980, reprinted in Kneisle, 1983), who later sketched an approach to geography he labelled "interventionist social geography", presents a critique of the ideology of science and of Länderkunde.

The role of Marxism in the controversy following $T G$ was a marginal one. At a time when Marx-inspired geography had its heyday in the US and while Marxism was still powerful in many other disciplines in West Germany, it was either invoked instrumentally (Dürr), dismissed on political grounds (Wirth) or ignored (as in the reactions to Petersen and Kneisle) in German geography. Marxian arguments were successfully kept out: they played no role in the struggles over hegemony, and were, we conclude, placed outside of what was seen as discussable. This brief sketch gives an idea of the historical background of today's many turns.

\section{Critical geography in the current debate over Neue Kulturgeographie}

\subsection{Radical positions in the 1980s and 90s}

While in the early 1980s, the main strand of critical theory in geography was still Marxist, in the meantime, the definition of what is "critical" has become much broader. The 1980s saw strong student activities within geography, particularly criticizing the history of the discipline. International debates became more important in German geography. For example, from the early 1990s onwards regulation theory was imported, mainly via German sociology and political science. While some geographers treated regulation theory as a critical theory of society (cf. Danielzyk, 1992; Danielzyk and Ossenbrügge, 1996; Hitz et al., 1992; Krätke, 1996; Ossenbrügge, 1992; cf. also the Marxian critique by 
Frieling, 1996), it was depoliticised within wide parts of the discipline. Bathelt (1994), for example, dismisses its "Marxian background" (ibid.:64) outright as an "ideological" one (ibid.) that makes many early contributions of the French school "difficult to understand" (ibid.). Also, beginning in mid-1980s, feminism started to enter German geography (for example Binder, 1989; Wastl-Walter, 1985).

We want to refrain from trying to come up with a review of all attempts to work with "critical" approaches in German geography in the 1980s and 90s. Instead, we will focus on a recent controversy over hegemony as exemplified in the main current debate in German geography - that of a "cultural turn". It is within this "cultural turn" that the position of critical approaches in geography has been strengthened. The debate is centred on an edited volume entitled Kulturgeographie $(K G)$ which, according to the editors' introduction, includes many "turns", cultural, semiotic, and postmodern, a "colourful" (Gebhardt et al., 2003b:9) "many things go" (ibid.).

Although theme issues of the German journals Berichte zur deutschen Landeskunde (2003) and Petermanns Geographische Mitteilungen (2003) also focussed on "Neue Kulturgeographie" (new cultural geography), the book, its editors and some of the contributors have come to represent the movement in German geography and as a result were subjected to a large number of appraisals, critiques and counter critiques in almost all German geography journals (Arnold, 2004; Ehlers, 2005a; Freytag and Jahnke, 2003; Heinritz, 2005; Klüter, 2005a, b). Therefore, the controversy around $K G$ can be used to analyse the different positions within the struggle over hegemony in German geography today. The "cultural turn" in German geography, as exemplified by $K G$, is a very broad movement of (post-) modernisation. In Anglophone geography, some of the contributions in $K G$, drawing mainly on social theory, would hardly be considered as cultural geography (like Watts' and Bohle's contribution on political ecology or Glückler's and Bathelt's chapter on economic geography). Also in contributions following $K G$ that position themselves implicitly or explicitly within the context of Neue Kulturgeographie, theoretical reference points vary a lot (cf. Gebhardt et al., 2007; Lossau, 2008) and include social theorists such as Bourdieu (Lippuner, 2005), Giddens (Schlottmann, 2005), Marx (Belina, 2008b) or Luhmann (Pott, 2005). Thus, $K G$ and Neue Kulturgeographie can only be understood as comprising anything that is "new" in the German debate. ${ }^{4}$ Other chapters of $K G$ are general introductions to key terms of cultural theory, others deal with topics like critical geopolitics or gender and identity construction.

$K G$ is especially relevant for the question about the left in German geography because one of the novelties of the book

\footnotetext{
${ }^{4}$ One aspect of the debate over Neue Kulturgeographie revolves around the question of its novelty and position in the history of the discipline (cf. Ehlers, 2007; Wardenga, 2005).
}

is that it claims a greater openness about "political ambitions" in academic debates. In the introduction, the editors include a subchapter titled "Cultural geography as a politically ambitious geography?" They start off by stating that normativity is always implicit in research and that therefore cultural geography is always a form of political geography. They pose the question of the ("at least temporary") political/normative positioning of geographers and muse about different possibilities to do so. As it is probably the longest and most prominent statement within mainstream German geography about critical geography in the last 20 years, it deserves being quoted in its entirety:

"Altogether, the positions reach from a rather conceptually oriented and thus rather implicitly normative form [of geography] to a close connection between scientific work and political agitation. For the latter, the normative point of perspective of most authors can be described somewhat pointedly as a left-oriented, social-critical position, following the humanist tradition, democracy and the ideals of the French revolution ('idealistic perspective'). It continues the critical tradition which Anglo-American cultural geography established with radical geography around David Harvey [... ]. It would certainly be possible to create further boxes for the ordering of political positionality. At a closer look, however, not only most of the contributions, but also their authors are 'different', fragmented and polyvalent in their political position." (Gebhardt et al., 2003b:21f.)

The editors do not themselves claim to be "left-oriented" - but they claim to include this "positionality" in their approach. As discussed earlier, in the 1980s debate the reference to Marxism was used in the abstract and instrumentally as either necessary for an "open" geography (Dürr, 1979) or as something to be excluded from a "pluralist" one (Wirth, 1980). As in the 1980 s, the editors of $K G$ identify themselves as open and pluralist. They define their pluralism explicitly through an inclusion of critical geography (and Marxism, although it is not mentioned directly) that is not only paying lip service to international developments (as in Dürr, 1979:52f). Rather, they do in fact include contributions by Doreen Massey (2003), Edward Soja (2003) and Michael Watts (Watts and Bohle, 2003). Among the German contributions, one is feminist/poststructuralist (Strüver, 2003) and another Marxist (Belina, 2003), both drawing strongly on Anglo-American literature. In the context of Neue Kulturgeographie, inclusion of critical geography becomes a symbol of pluralism.

The whole topic of left political positionality was however not important in the controversy following $K G$, at least not explicitly. Although Klüter (2005a, b) makes some allusions toward the politics implicit in $K G$ (see below), the harsh critiques of the book focus on other issues. But still, analysing them can highlight the state of the struggle over hegemony in German geography and the situation of the left within it.

Earlier we pointed out how institutional hierarchy structured the debate of the 1980s. Looking at the critiques of 
$K G$, there is at least as much evidence of a hierarchy shaping the debate. ${ }^{5}$

Among the critiques, two stand out, mainly due to their length and the references they have drawn. In Geographische Rundschau, the main popular/academic German geography journal, a review by Eckart Ehlers, professor emeritus from Bonn, was entitled German geography - Geography in Germany - Where are you going? (Ehlers, 2005a). Ehlers emphasises what he views to be a lack of "clarity" in Neue Kulturgeographie. As a self-labelled "representative of what might be called 'traditionalist' geography" he observes an absence of "objectively and scientifically derived" positions and "unique" questions for the discipline. Also ("in the interest of geography"), he observes a lack of questions relevant for problem solving and applications (ibid.:53). Finally, he particularly challenges the book's failure to grasp the unity of the discipline: "Unity of geography requires an active confession to Allgemeiner Geographie ["general", i.e. physical and human geography] and its subject areas" (ibid.:54; cf. Ehlers, 2005b, 2007). In the same issue of the journal, Günter Heinritz (2005), professor in Munich and former president of the Association of German geography professors [Verband der Geographen an deutschen Hochschulen; $V G D H]$, also reviews $K G$. His critique, although in parts offensive to individual contributions, is more balanced. However, he clearly repeats the main point of Ehlers' "traditionalist" critique, complaining "about a discipline that has lost its classic anchors, so that its outside image seems not clearly contoured, but contradictory and fragmented" (Heinritz, 2005:62). Both authors place the fate of "German geography" at the centre of their concern. ${ }^{6}$

The second extended critique was by Helmut Klüter (2005a). Its title, Geography as feuilleton, has become a key slogan in the controversy. ${ }^{7}$ The expression "geography as feuilleton" has been taken up as meaning superficiality, a "journalistic" style and a lack of "scientific analysis". Klüter criticizes $K G$ 's regression behind the standards of the socialscientific turn in geography (which he equates with criti-

\footnotetext{
${ }^{5}$ The harshest critiques came from established professors, remarkably soft critiques from $\mathrm{PhD}$-students/postdoctoral lecturers (for example Freytag and Jahnke, 2003). Furthermore, the harshest professorial critiques were directed at the "weakest links" of the book - at the contributions by PhD-students and postdocs. Heinritz (2005) for example singles out Anke Strüver's (2003) feminist critique of identity, Klüter (2005a) targets Strüver, Julia Lossau (2003) and Wolfgang Zierhofer (2003) - all three not tenured professors at the time (in Klüter, 2005b, he does target the figureheads of the debate). It might be worth mentioning that the only critique "from the left", the Marxist critique by Heinz Arnold (2004), focuses on the contributions of the "big names" like Doreen Massey.

${ }^{6}$ This criticism of geography is not exclusive to $K G$ or Germany, but rather common to all disciplines and all eras of geography, as Don Mitchell rightly points out in his reviewer's comment.

7 The feuilleton is the arts and culture section of a newspaper, in a more traditional use comparable to "society" pages.
}

cal rationalism and, somewhat unusually, Luhmann's systems theory). Neue Kulturgeographie in his opinion replaces analysis with ontology and ambiguity, and means a return to "old" cultural geography: "all the achievements of economic and social geography are wiped away and become victims of an erratic subjectivism" (ibid.:135).

It is not our concern here that the "achievements of economic and social geography" listed by Klüter are all formulated in the terms of a Luhmann-inspired geography. What is of interest to us is that his critique is voiced from a different perspective than Ehlers' and Heinritz's. His main concern is that geography must be "scientific", not superficial, rational, not subjective. Like Ehlers', Klüter's concern is "German geography". But his standpoint is a different one. His geography is an applied social science. It is not a unified geography - as with Ehlers - but a rational one, loosely based on the "scientific turn" of the Kiel Geographentag. His critique also has a political twist. Building on his accusation that $K G$ lacks scientific rigour, Klüter goes on to suggest that Neue Kulturgeographie is (unknowingly) right-wing, as it repeats the pitfalls of Spengler, Heidegger or Haushofer by reintroducing the idea of culture (Klüter, 2005a:127). As mentioned earlier, this is one of the rare times that political aspects surface in the $K G$ controversy. Apart from this, for Klüter Neue Kulturgeographie is apolitical, because it does not deal with formal politics: elections, lobbyism, presidents, parliaments and the like (ibid.:130f.).

\subsection{Neue Kulturgeographie: more international than critical}

Klüter's critique was followed by a lengthy reply from Sahr (2005), one of the contributors to $K G$. Sahr's reply as well as his chapter in the edited volume (Sahr, 2003) contain the central counterargument to the critics who worry about "German geography": the increased global connectivity of German Neue Kulturgeographie. His initial book chapter illustrates the history of German (cultural) geography by comparing it to a ship. Formerly a mighty battleship, it became a coaster with engine trouble in the 1980s (Sahr, 2003:240), but one that now has regained a potential that could bring it back into the high seas and towards the "horizon of international social science" (ibid.:245). His reply to Klüter (2005a), titled News from the Flying Dutchman (taking up a joke by Klüter), reiterates that image. Sahr stresses the unique contribution of $K G$ to German geography's connection to international debates. The book "addresses a very heterogeneous audience, including older colleagues who have traditionally not been dealing with international theory debates in geography (but who are curious) and young academics and students looking for a connection to current debates in the social sciences" (Sahr, 2005:501; our emphasis). Sahr presents this new German geography as more inclusive, more open towards "critical" approaches. In this context, he compares the current situation with the 1980s when German "geographers were mea- 
sured not so much according to their intellectual qualities, but their suitability for (discipline) politics" (ibid.:507). This, according to Sahr, is different today as Neue Kulturgeographie differs from old geography not only in content and openness, but also in ethos and atmosphere.

In stressing the international character of $K G$, Sahr also goes beyond the concern for German geography that dominated the debate around 1980, and that drives much of the critique of $K G$. This points towards a shift in the rules within the discipline and therefore the construction of hegemony within it. Sahr suggests that the dominant rule of the 1980 s - the disciplinary power of the discipline - no longer applies as German geography is no longer a "national geography" (Petersen, 1980:3) but part of a global discourse. However, the standard for "good geography" of that time is still present in the critiques of Klüter, Heinritz and Ehlers who, in a later paper, explicitly stresses and bemoans the fact that German cultural geography has become an "importer" of ideas from Anglo-American geography (Ehlers, 2007). Their question, although answered differently, is: "What does this approach do for German geography (within the German university system)?" The "new" question asked by Sahr and $K G$ is "How does this contribute to the standing of German geographers in international debates?"

\section{Inclusion of critical voices via internationalisation - chances and ambivalences}

It has become clear that whereas in the 1980s, we had to ask how the exclusion of critical perspectives was achieved, with regard to the current debate our question is much more about the details of their inclusion. The "traditionalist" actors still operate on a discourse of exclusion. "What should be part of the discipline? What is in the interest of the discipline?", ask the conservative critics of $K G$, therefore defining themselves as those setting the disciplinary boundaries. However, these conservative critics have not diminished the success of $K G$ - the term "Neue Kulturgeographie" has become a relevant marker and, for example, shows up in job adverts for professors. The disciplinary discourse has shifted. In the new formulation of disciplinary space, critical geography is - via Neue Kulturgeographie - explicitly included, and some arguments of international critical geography have gained importance. This does not mean, of course, that there are a lot of critical geographers in permanent positions in German academia today. This is, however, a peculiar critical turn that is to a certain degree a top-down process initiated by powerful professors, and that has a strong focus on "culture" and cultural geography - as opposed to "classical" concerns of radical geographers in social and economic geography. What we find especially interesting in the process is the importance of "international", i.e. Anglo-American debates.

The new question of German geography ("How does this contribute to the standing of German geographers in inter- national debates?") and the shift in disciplinary rules it stands for is highly relevant for critical geography in Germany. As one important strand of international geography and social/cultural theory is rooted in radical schools of thought, these can be referred to and worked with more easily these days - not because they are critical, but because they are international and internationally successful. This brings us back to the "geographies of critical geography". In that debate, many commentators criticise the "hegemony" of Anglo-American critical geography within other, national or language based geographies (Berg, 2004; Berg and Kearns, 1998; Garcia-Ramon, 2004; Minca, 2000; Simonsen, 2004). Some point especially to the uneven relationship between Anglo-American and non-Anglo-American radical geographers that results from this (Timár, 2004; Yiftachel, 2003). While we think that especially critical and radical geographers have to be aware of the "language question" as well as in the agenda setting power of Anglo-American critical geography, our discussion of the German case highlights the positive aspects of the role of international/Anglo-American theory in national debates. Not only are these theories sources of inspiration for German critical geographers, they are also important in influencing German geographical discourse and allowing critical perspectives to enter mainstream geography. Not un-similar to the situation described by Vaiou (2004) for Greece who writes about the influence of French critical theory, German critical geography profits from the "hegemony" of Anglo-American radical geography. As Englishlanguage critical geography is ranked higher internationally than even the most mainstream German geography, in the context of German geography's attempts to internationalise, critique can be imported (or, as in the case of Marxism, reimported) from international critical debates. This positive influence of international debates for German critical geography does not come without ambivalences, though.

First, there is the danger of critical approaches being used in an instrumental manner. As with Dürr's (1979) call for an openness towards Marxism or with Bathelt's (1994) use of regulation theory in the 1990s, calling for or using explicitly critical and left wing theories in an instrumental manner can lead to their depolitisation.

Second, using "international excellence" strategically to import left wing theories can foster the import of the more troublesome aspects of 'excellence' (cf. Mitchell, 2000), among others the implementation of performance measurements. In recent years, attempts were made on the parts of mainstream geography to use these other aspects of "internationalisation" as a means of policing German geographical discourse. Emerging from within the powerful association of university geographers $V G D H$, a list of "recognized" German geography journals was introduced alongside a call for a stronger ranking of journals (see Sternberg, 2001, 2004). The main points of reference here are citation indices and rankings of English-language geography journals. Sternberg openly hopes for a "steering effect" (2004:7), for 
greater differentiation (into highly and lowly ranked journals; cf. 2001:11) and wishes publication lists to become easy to assess in evaluations, institutional rankings and job appointments. In another project, he has come up with a ranking of German economic geographers (Sternberg and Stockinger, 2007) in which only SSCI- and SCI listed articles count. This is the sinister side of internationalisation in German geography, a very much top-down process not at all enabling for critical geography.

Coming back to our initial observation concerning German geography's move towards the left, we can summarize the arguments made so far: while around 1980 critical geography - as exemplified by Marxism at that time - was outside of the possible in German geography, critical geography of the Marxist, feminist or otherwise leftist kind is, up to a certain degree, included some 20 years later. Although the political aspects of this have remained uncommented upon within the discipline, the context of its inclusion - Neue Kulturgeographie - is facing harsh critiques. These are not related with being "critical" per se, but they do shed light on the conditions under which critical geography is possible in Germany. Guardians of geography as a (national) discipline in particular regard $K G$ (and the openness it stands for) as a catastrophe for German geography. These fears are countered by its proponents through applying another standard, one of German geography's catching up with international (i.e. mainly Anglo-American) geography discourse. As discussed, this does open up German geography to critical positions, and we think this is the reason why there is the possibility for voices from the left to gain in importance. The inclusion is however highly ambivalent both in its content and in its context.

\section{Conclusion: the conditions of inclusion - critical geography in Germany and the "Anglo-hegemony"}

Is there an Anglo-hegemony in German geography? No. We did not present a full review of the developments in German cultural geography, but such a review would not only show a time lag, but also deviations from Anglo-American cultural geography. Although German geography in many ways lags behind and repeats theoretical developments in Anglophone geography, there are many differences, e.g. more reference to social theory of the "grand narrative" kind (cf. Hannah, 2006:241) and very little awareness of the political nature of geographical research. The explaining factor for the adoption of Anglo-American approaches is not an unequal power relation between Anglophone and German geographers. In the German discipline, a modernist elite is being supplemented by one defining themselves as "new cultural geographers". The struggles we observe are between the old, traditionalist elite, the modernisers who replaced the traditionalists and the new modernisers (or "postmodernisers"). This parallels a wider transformation of the university system which also highly values internationalisation, but it uses it for a specific purpose.

In our paper, we have tried to show the working of the power structures of the still nationally confined discipline, their transformation over the last 30 years and the different opportunities and ambivalences this means for critical geography. As a contribution to the debate about the "geography of critical geography", this demonstrates the high significance of national systems and their relation with internationalisation and international debates. In contrast to many contributions to the debate on the "Anglo-hegemony", the main difference we draw is not between "Anglo" and "nonAnglo" approaches, but between critical approaches and traditional/mainstream ones. While there may be some countries where this distinction has become blurred and needs to be debated at large (like in the "what's left"-debate in Antipode), this line in Germany is still rather clear, due to the power of traditional/mainstream geography. We have defined "critical geography" through the exclusion from this mainstream and the various and ambivalent mechanisms of inclusion. It is in these processes of inclusion that the idea of "international" geography becomes important - not because any of the central figures of the international debate had any institutional power in Germany, but because institutional power in Germany has shifted. The "old" defining question in German geography - "What does this approach do for German geography as a unified discipline?" - has been replaced by a "new" question - "How does this approach contribute to the standing of German geographers in international debates?" From the traditional Ordinarien, hegemony and institutional power have partly shifted to "new voices", who embrace international geography, sometimes including critical theorizing, but also to consulting and ranking agencies. Thus, while the new "internationalizing" question opens up spaces for critical and left wing theory, it may come with a price.

Acknowledgements. This article has a bit of a history, beginning with discussions within our "Berlin group" with Dirk Gebhardt and Tom Bürk that resulted in an ongoing (side) project in which we try to reconstruct the marginal history of the left in West German academic geography (cf. Belina, 2008a:335; Best, 2009). First results were presented in the session "Left Geographies?" at the 2006 RGS/IBG annual conference in London and at the Neue Kulturgeographie $V$ conference in Jena in 2008. Various friends and colleagues have commented on earlier versions of this paper or have otherwise helped us with this project: Bernd AdamekSchyma, Wolfgang Aschauer, Mark Blacksell, Jonas Bylund, Salvatore Engel-Di Mauro, Katharina Fleischmann, Michael Flittner, Hans-Dieter von Frieling, Eva Gelinsky, Carsten Gräbel, Gesa Helms, Benedikt Korf, Doreen Massey, Eric Sheppard, Anke Strüver and Ute Wardenga, as did two referees for Social Geography, Harald Bauder and Don Mitchell and SG's editor for this paper, Matt Hannah. We are indebted to all of them without making them responsible for the outcome.

Edited by: M. Hannah 


\section{References}

Althusser, L.: Ideologie und ideologische Staatsapparate, VSA, Hamburg and Berlin, 1977 [1970].

Arnold, H.: Review of Gebhardt, Reuber \& Wolkersdorfer (2003): Kulturgeographie, Geographische Revue, 6(2), 99-103, 2004.

Bahrenberg, G.: Die Länderkunde im Paradigmenstreit um 1970, Berichte zur deutschen Landeskunde, 70(1), 41-54, 1996.

Bahrenberg, G.: Anmerkungen zu E. Wirths vergeblichem Versuch einer wissenschaftstheoretischen Begründung der Länderkunde, Geogr. Z., 67(2), 147-157, 1979.

Bahrenberg, G.: Räumliche Betrachtungsweise und Forschungsziele der Geographie, Geogr. Z., 60, 8-24, 1972.

Bartels, D.: Die konservative Umarmung der Revolution, Geogr. Z., 68(2), 121-131, 1980.

Bartels, D.: Zur wissenschaftstheoretischen Grundlegung einer Geographie des Menschen, Wiesbaden, 1968.

BASSDA: A Kind of Queer Geography/Räume Durchqueeren: The Doreen Massey Reading Weekends, Gender Place Cult., 13(2), 173-186, 2006.

Bathelt, H.: Die Bedeutung der Regulationstheorie in der wirtschaftsgeographischen Forschung, Geogr. Z., 82(2), 63-90, 1994.

Beck, G.: Erklärende Theorie und Landschaftskunde, Universität Karlsruhe, Karlsruhe, 1985.

Beck, G.: Zur Kritik der bürgerlichen Industriegeographie, Selbstverlag, Göttingen, 1973.

Belina, B.: Kritische Geographie: Bildet Banden! Einleitung zum Themenheft, ACME, 7(3), 335-349, 2008a.

Belina, B.: "We may be in the slum, but the slum is not in us!" Zur Kritik kulturalistischer Argumentationen am Beispiel der underclass-Debatte, Erdkunde, 61(1), 15-26, 2008b.

Belina, B.: Kultur? Macht und Profit!, in: Kulturgeographie, edited by: Gebhardt, H., Reuber, P., and Wolkersdorfer, G., Spektrum, Heidelberg, 83-97, 2003.

Berg, L. D.: Scaling knowledge: towards a critical geography of critical geographies, Geoforum, 35(5), 553-558, 2004.

Berg, L. D. and Kearns, R.: America Unlimited, Environ. Plann. D, 16(2), 128-132, 1998.

Berichte zur deutschen Landeskunde: Theme issue on "Neue Kulturgeographie", Berichte zur deutschen Landeskunde, 77(1), 5104, 2003.

Berliner Geographenkreis (Ed.): Sonderheft zum 37. Deutschen Geographentag, Geografiker, 3, 1969.

Best, U.: Critical Geography, in: The International Encyclopedia of Human Geography, edited by: Kitchin, R. and Thrift, N., Elsevier, Oxford, Vol. 2, 345-357, 2009.

Binder, E.: Männerräume - Männerträume. Ebenen des Androzentrismus in der Geographie, in: Materialien zur Didaktik der Geographie und Wirtschaftskunde, 4, edited by: Vielhaber, C. and Wohlschlägl, H., Wien, 1989.

Blomley, N.: Uncritical critical geography?, Prog. Hum. Geog., 30(1), 87-94, 2006.

Bretthauer, L. and Fromberg, D.: Prekarisierung und Marginalisierung der Kritik, in: Prekarisierung der Wissenschaft, edited by: Bultmann, T., BdWi, Berlin, 23-40, 2008.

Brüchert, O. and Wagner, A. (Eds.): Kritische Wissenschaft, Emanzipation und die Entwicklung der Hochschulen. Reproduktionsbedingungen und Perspektiven kritischer Theorie, BdWi, Marburg, 2007.
Brünneck, A.: Politische Justiz gegen Kommunisten in der Bundesrepublik Deutschland 1949-1968, Suhrkamp, Frankfurt a.M., 1978.

Bultmann, T. (Ed.): Prekarisierung der Wissenschaft, BdWi, Berlin, 2008.

Bultmann, T. and Schöller, O.: Die Zukunft des Bildungswesens: Lernen auf Abruf, Prokla, 131, 331-354, 2003.

Castree, N.: Geography's new public intellectuals?, Antipode, 38(2), 396-412, 2006.

Castree, N.: Professionalism, activism, and the university: whither 'critical geography'?, Environ. Plann. A, 32(6), 955-970, 2000.

Claval, P.: Le Marxisme et l'espace, L'Espace Géographique, 3, 145-164, 1977.

Danielzyk, R. and Ossenbrügge, J.: Lokale Handlungsspielräume zur Gestaltung internationalisierter Wirtschaftsräume, Z. Wirtsch., 40(1+2), 101-112, 1996.

Danielzyk, R.: Gibt es im Ruhrgebiet eine „Postfordistische Regionalpolitik”, Geogr. Z., 80(2), 84-105, 1992.

Demirovic, A.: Materialistisches Wissen - kritische Theorie: die Assoziation für kritische Gesellschaftsforschung, SPW, 147, 33 35, 2006 .

Dürr, H.: Für eine offene Geographie, gegen eine Geographie im Elfenbeinturm, Universität Karlsruhe, Karlsruhe, 1979.

Ehlers, E.: Deutsche Kulturgeographie im 20. Jahrhundert, Geographische Rundschau, 59(7/8), 4-11, 2007.

Ehlers, E.: Deutsche Geographie - Geographie in Deutschland. Wohin des Weges?, Geographische Rundschau, 57(9), 51-57, 2005a.

Ehlers, E.: Mensch-Umwelt-Beziehung als geographisches Paradigma, in: Allgemeine Anthropogeographie, edited by: Schenk, W. and Schliephake, K., Perthes, Gotha, 769-783, 2005b.

Eisel, U.: Regionalismus und Industrie, in: Kultur/Sozialgeographie, edited by: Sedlacek, P., UTB, Paderborn, 125-150, 1982.

Eisel, U.: Die Entwicklung der Anthropogeographie von einer „Raumwissenschaft” zur Gesellschaftswissenschaft, Gesamthochschule Kassel, Kassel, 1980.

Engels, F.: Die Lage der arbeitenden Klasse in England, in: MarxEngels-Werke 2, Dietz, Berlin, 256-305, 1976[1845].

Fahlbusch, M.: Die verlorene Ehre der deutschen Geographie, Frankfurter Rundschau, 02.10.1999.

Fleischmann, K. and Meyer-Hanschen, U.: Stadt - Land - Gender. Einführung in Feministische Geographien, Helmer, Königstein i.Ts., 2005.

Freytag, T. and Jahnke, H.: Rezension „Kulturgeographie”, Die Erde, 134(2), 213-215, 2003.

Frieling, H.-D.: Zwischen Skylla und Charybdis, Z. Wirtsch., 40(1+2), 80-88, 1996.

Frieling, H.-D.: Räumliche soziale Segregation in Göttingen. Zur Kritik der Sozialökologie, Gesamthochschule Kassel, Kassel, 1980.

Ganser, K.: Thesen zur Ausbildung des Diplomgeographen, in: Deutscher Geographentag Kiel, 21. bis 26. Juli 1969, Tagungsbericht und wissenschaftliche Abhandlungen, edited by: Meckelein, W. and Borcherdt, C., Steiner, Wiesbaden, 183-190, 1970.

Garcia-Ramon, M.-D.: The spaces of critical geography: an introduction, Geoforum, 35(5), 523-524, 2004.

Gebhardt, H., Glaser, R., Radtke, U., and Reuber, P. (Eds.): Ge- 
ographie, Spektrum, Heidelberg, 2007.

Gebhardt, H., Mattissek, A., Reuber, P., and Wolkersdorfer G.: Neue Kulturgeographie? Perspektiven, Potentiale und Probleme, Geographische Rundschau, 59(7/8), 12-21, 2007.

Gebhardt, H., Reuber, P., and Wolkersdorfer, G. (Eds.): Kulturgeographie, Spektrum, Heidelberg, 2003a.

Gebhardt, H., Reuber, P., and Wolkersdorfer, G.: Kulturgeographie - Leitlinien und Perspektiven, in: Kulturgeographie, edited by: Gebhardt, H., Reuber, P., and Wolkersdorfer, G., Spektrum, Heidelberg, 1-27, 2003b.

Geographische Revue (Ed.): Theme issue on „Kritische Geographie“, Geographische Revue, 10(2), 5-77, 2008.

Geographische Revue (Ed.): Theme issue on "Marxism in Geography”, Geographische Revue, 3(2), 3-54, 2001.

Glückler, J. and Bathelt, H.: Relationale Wirtschaftsgeogrephie: Grundperspektiven und Schlüsselkonzepte, in: Kulturgeographie, edited by: Gebhardt, H., Reuber, P., and Wolkersdorfer, G., Spektrum, Heidelberg, 171-190, 2003.

Gössner, R.: Die vergessenen Justizopfer des Kalten Krieges, Aufbau, Berlin, 1998.

Gould, P.: The only perspective: a critique of Marxist claims to exclusiveness in geographical inquiry, in: A ground for common search, edited by: Golledge, R., Couclelis, H., and Gould, P., St. Barbara Geographical Press, St. Barbara, 1-10, 1988.

Gramsci, A.: Philosophie der Praxis: Gefängnishefte 10 und 11, edited by: Haug, W. F., Argument, Hamburg, 1995.

Gramsci, A.: Philosophie der Praxis: Gefängnishefte 6 und 7, edited by: Bochmann, K. and Haug, W. F., Argument, Hamburg, 1992.

Hannah, M.: Politics in suspenso: Reading Antje Schlottmann's RaumSprache from the 'North American' Container, ACME, 4(2), 240-248, 2006.

Hard, G.: Die Geographie, De Gruyter, Berlin and New York, 1973.

Hartke, W.: Die „Sozialbrache” als Phänomen der geographischen Differenzierung der Landschaft, Erdkunde, 11, 257-269, 1956.

Haug, W. F.: From Marx to Gramsci, from Gramsci to Marx: Historical Materialism and the Philosophy of Praxis, Rethinking Marxism, 13(1), 69-82, 2001.

Heinrich, H.-A.: Politische Affinität zwischen geographischer Forschung und dem Faschismus im Spiegel der Fachzeitschriften, Universität Gießen, Gießen, 1991.

Heinritz, G.: Kulturgeographie - A Changing Discipline?, Geographische Rundschau, 56(2), 62-63, 2005.

Hitz, H., Schmid, C., and Wolff, R.: Zur Dialektik der Metropole: Headquarter Economy und urbane Bewegungen, Geogr. Z., 80(2), 67-83, 1992.

Kilchenmann, A.: Foreword, in: Für eine offene Geographie, gegen eine Geographie im Elfenbeinturm, edited by: Dürr, H., Universität Karlsruhe, Karlsruhe, 1-3, 1979.

Klüter, H.: Geographie als Feuilleton, Berichte zur deutschen Landeskunde, 79(1), 125-136, 2005a.

Klüter, H.: Kultur als Ordnungshypothese über Raum?, Geographische Revue, 7(1+2), 43-66, 2005 b.

Kneisle, A.: Es muß nicht immer Wissenschaft sein ... Methodologische Versuche zur Theoretischen und Sozialgeographie in wissenschaftsanalytischer Sicht, Gesamthochschule Kassel, Kassel, 1983.

Kneisle, A.: „Offene” Wissenschaftstheorie oder Anbiederung an die Forschergemeinde, Universität Karlsruhe, Karlsruhe, 1980.
Krätke, S.: Regulationstheoretische Perspektiven in der Wirtschaftsgeographie, Z. Wirtsch., 40(1+2), 6-19, 1996.

Leng, G.: Zur „Münchner” Konzeption der Sozialgeographie, Geogr. Z., 61, 121-134, 1973.

Lenin, W. I.: Der Imperialismus als höchstes Stadium des Kapitalismus, in: Ausgewählte Werke I, Dietz, Berlin, 1965[1917].

Lippuner, R.: Reflexive Sozialgeographie: Bourdieus Theorie der Praxis als Grundlage für sozial- und kulturgeographisches Arbeiten nach dem cultural turn, Geogr. Z., 93(3), 135-147, 2005.

Lossau, J.: Kulturgeographie als Perspektive. Zur Debatte um den cultural turn in der Humangeographie - eine Zwischenbilanz, Berichte zur deutschen Landeskunde, 82(4), 317-334, 2008.

Lossau, J.: Geographische Repräsentationen: Skizze einer anderen Geographie, in: Kulturgeographie, edited by: Gebhardt, H., Reuber, P. and Wolkersdorfer, G., Spektrum, Heidelberg, 101-111, 2003.

Markard, M.: Wissenschaft, Kritik und gesellschaftliche Herrschaftsverhältnisse, in: Kritische Wissenschaft im Neoliberalismus, edited by: Kaindl, C., BdWi, Marburg, 19-30, 2005.

Massey, D.: Spaces of Politics - Raum und Politik, in: Kulturgeographie, edited by: Gebhardt, H., Reuber, P., and Wolkersdorfer, G., Spektrum, Heidelberg, 31-46, 2003.

Minca, C.: Venetian geographical praxis, Environ. Plann. D, 18(3), 285-289, 2000.

Mitchell, D.: Geography in an Age of Extremes: A Blueprint for a Geography of Justice, Ann. Assoc. Am. Geogr., 94(4), 764-770, 2004.

Mitchell, D.: Culturalism and Cultural Geography in the AngloAmerican 'University of Excellence', Geographische Revue, 2(2), 3-17, 2000.

Notz, G.: Geschlechterstereotypen und weibliche Karrieremuster in der Wissenschaft, in: Prekarisierung der Wissenschaft, edited by: Bultmann, T., BdWi, Berlin, 53-58, 2008.

Ossenbrügge, J.: Der Regulationsansatz in der deutschsprachigen Stadtforschung, Geogr. Z., 80(2), 121-127, 1992.

Peet, R.: Celebrating thirty years of radical geography. Professionalism, activism, and the university: whither 'critical geography'?, Environ. Plann. A, 32(6), 951-953, 2000.

Petermanns Geographische Mitteilungen: Theme issue on „Neue Kulturgeographie”, Petermann. Geogr. Mitt., 147(2), 6-83, 2003.

Petersen, V. C.: „Geographie”: Beschwörung, Leerformel oder Programm?, Universität Karlsruhe, Karlsruhe, 1980.

Popper, K.: Die Logik der Sozialwissenschaften, Kölner Z. Soziol. Soz., 14, 233-248, 1962.

Pott, A.: Kulturgeographie beobachtet: Probleme und Potentiale der geographischen Beobachtung von Kultur, Erdkunde, 59(2), 89-101, 2005.

Rössler, M.: „Wissenschaft und Lebensraum”. Geographische Ostforschung im Nationalsozialismus, Reimer, Berlin and Hamburg, 1990.

Ruppert, K. and Schaffer, F.: Zur Konzeption der Sozialgeographie, Geographische Rundschau, 21(6), 214-221, 1969.

Sahr, W.-D.: Neues vom Fliegenden Holländer, Berichte zur deutschen Landeskunde, 79(4), 501-514, 2005.

Sahr, W.-D.: Der Cultural Turn der Geographie, in: Kulturgeographie, edited by: Gebhardt, H., Reuber, P., and Wolkersdorfer, G., Spektrum, Heidelberg, 231-249, 2003. 
Sambale, J., Eick, V., and Walk, H. (Eds.): Das Elend der Universitäten. Neoliberalisierung deutscher Hochschulpolitik, Westfälisches Dampfboot, Münster, 2008.

Sandner, G. and Rössler, M.: Geography and Empire in Germany, 1871-1945, in: Geography and Empire, edited by: Godlewska, A. and Smith, N., Blackwell, Oxford, 115-127, 1994.

Sandner, G.: Die unmittelbare Nachkriegszeit: personelle, institutionelle und fachinhaltliche Aspekte 1945-1950, in: Kontinuität und Diskontinuität der deutschen Geographie in Umbruchphasen, edited by: Wardenga, U. and Hönsch, I., Universität Münster, Münster, 141-150, 1995.

Schenk, W. and Schliephake, K. (Eds.): Allgemeine Anthropogeographie, Perthes, Gotha, 2005a.

Schenk, W. and Schliephake, K.: Anthropogeographie - Begriffe und Standorte einer „Geographie des Menschen”, in: Allgemeine Anthropogeographie, edited by: Schenk, W. and Schliephake, K., Perthes, Gotha, 23-40, 2005b.

Schlottmann, A.: RaumSprache, Steiner, Stuttgart, 2005.

Schmidt-Renner, G.: Elementare Theorie der ökonomischen Geographie, Haack, Gotha, 1966.

Schmithüsen, J.: Die Aufgabenkreise der Geographischen Wissenschaft, Geographische Rundschau, 22, 431-437, 1970.

Sedlacek, P.: Pluralismus und Geographie. Anmerkungen zu einer Kontroverse falscher Propheten, Universität Karlsruhe, Karlsruhe, 1980 .

Simonsen, K.: Differential spaces of critical geography, Geoforum, 35(5), 525-528, 2004.

Smith, N.: Marxism and Geography in the Anglophone World, Geographische Revue, 3(2), 5-21, 2001.

Soja, E. W.: Thirdspace - Die Erweiterung des Geographischen Blicks, in: Kulturgeographie, edited by: Gebhardt, H., Reuber, P., and Wolkersdorfer, G., Spektrum, Heidelberg, 269-288, 2003.

Sternberg, R.: Bericht des wissenschaftlichen Beirates. Liste anerkannter Geographie-Zeitschriften, Rundbrief Geographie, 186, 4-7, 2004

Sternberg, R.: Liste anerkannter Geographie-Zeitschriften, Rundbrief Geographie, 170, 11-15, 2001

Sternberg, R. and Stockinger, D.: ZitArt - Erstes Publikationsund Zitationsranking deutschsprachiger Wirtschaftsgeographen, Rundbrief Geographie, 207, 14-15, 2007.
Strüver, A.: Macht Körper Wissen Raum? Ansätze für eine Geographie der Differenzen, Universität Wien, Wien, 2005.

Strüver, A.: "Das duale System": Wer bin ich - und wenn ja, wie viele? Identitätskonstruktionen aus feministischpoststrukturalistischer Perspektive, in: Kulturgeographie, edited by: Gebhardt, H., Reuber, P., and Wolkersdorfer, G., Spektrum, Heidelberg, 113-128, 2003.

Timár, J.: More than 'Anglo-American', it is 'Western': hegemony in geography from a Hungarian perspective, Geoforum, 35(5), 533-538, 2004.

Vaiou, D.: The contested and negotiated dominance of Anglophone geography in Greece, Geoforum, 35(5), 529-531, 2004.

Ward, K.: 'Public intellectuals', geography, its representations and its publics, Geoforum, 38(6), 1058-1064, 2007.

Wardenga, U. (2005): „Kultur” und historische Perspektive in der Geographie, Geogr. Z., 93(1), 17-32, 2005.

Wardenga, U. and Böhm, H.: Das kollektive Vergessen findet nicht statt, Frankfurter Rundschau, 15.10.1999.

Wastl-Walter, D.: Geographie - eine Wissenschaft der Männer?, in Festschrift für Elisabeth Lichtenberger, edited by: Backe, B. and Seger, M., Universität Klagenfurt, Klagenfurt, 157-169, 1985.

Watts, M. and Bohle, H.-G.: Verwundbarkeit, Sicherheit und Globalisierung, in: Kulturgeographie, edited by: Gebhardt, H., Reuber, P., and Wolkersdorfer, G., Spektrum, Heidelberg, 67-82, 2003.

Wirth, E.: Die Blickverengung einer „Offenen Geographie” und das Märchen vom Elfenbeinturm, Universität Karlsruhe, Erlangen and Karlsruhe, 1980.

Wirth, E.: Theoretische Geographie, Teubner, Stuttgart, 1979.

Wirth, E.: Zur wissenschaftstheoretischen Problematik der Länderkunde, Geogr. Z., 66(4), 241-261, 1978.

Wittfogel, K. A.: Geopolitik, Geographischer Materialismus und Marxismus (3 parts), Unter dem Banner des Marxismus, 3, 17 51, 485-522 and 898-935, 1929.

Yiftachel, O.: Relocating the Critical: Reflections from Israel/Palestine, Environ. Plann. D, 21(2), 137-147, 2003.

Zierhofer, W.: Natur - das Andere der Kultur?, in: Kulturgeographie, edited by: Gebhardt, H., Reuber, P. and Wolkersdorfer, G., Spektrum, Heidelberg, 193-212, 2003. 